\title{
PATCH FORMATION AND MAINTENANCE IN AN OLD-GROWTH HEMLOCK-HARDWOOD FOREST ${ }^{1}$
}

\author{
Lee E. Frelich, ${ }^{2}$ Randy R. Calcote, and Margaret B. Davis \\ Department of Ecology, Evolution and Behavior, University of Minnesota-Twin Cities, \\ Minneapolis, Minnesota 55455 USA \\ JOHN PASTOR \\ Natural Resources Research Institute, University of Minnesota-Duluth, \\ Duluth, Minnesota 55812 USA
}

\begin{abstract}
Cause of patch formation was investigated on a 7.2 ha study area in Sylvania Wilderness Area, a primary forest remnant in Upper Michigan comprising a mosaic of hemlock, sugar maple, and mixed-forest patches. Spatial autocorrelation analysis of the stem map indicates that, although most species pairs have a neutral association between canopy trees and understory trees of other species, hemlock and sugar maple canopy trees both have strong positive self association and negative reciprocal association with each other. No species pairs have a positive reciprocal association on regeneration with each other.

MOSAIC, a Markov simulation model in which transition probabilities depend on neighborhood species composition, shows that the negative reciprocal association between hemlock and sugar maple of the intensity observed in this study, could lead to spatial separation into monodominant patches over long time periods ( $3000 \mathrm{yr})$. The mixed-forest patches are along spatial continua of varying steepness between sugar maple and hemlock patches. Interactions between sugar maple and hemlock overstory and understory trees, along with the pattern of invasion of hemlock, provide a reasonable explanation for the patch structure. Pedological, topographical, and disturbance history differences do not coincide with the location of patches within upland forests on the study area.
\end{abstract}

Key words: eastern hemlock; landscape ecology; long-term competition; neutral association; old growth; patch dynamics; reciprocal association; sugar maple; Sylvania; Upper Michigan.

\section{INTRODUCTION}

Spatial patchiness of vegetation has been a subject of major interest to ecologists. Much effort has been devoted to determining the relative impact of abiotic and biotic factors on the species composition of patches (Hubbell and Foster 1986). Recent studies highlight biotic factors as a cause of stand formation in some vegetation types. Hart et al. (1989) and Connell and Lowman (1989) propose that superior competitive ability of species with large seeds, shade tolerance, or ectomycorrhizae results in formation of monodominant stands within species-rich tropical forests. Similarly, clonal growth form, herbivory by large grazers, strong seed rain, and nutrient-dynamic feedbacks influence the relative success of species in grassland vegetation (Thompson 1985, Belsky 1986, Schlesinger et al. 1990, Wedin and Tilman 1990). These biotic interactions influence the outcome of competition among species, and may result in formation of patches that cross pedologic and disturbance boundaries.

\footnotetext{
'Manuscript received 14 August 1991; revised and accepted 14 May 1992.

${ }^{2}$ Present address: Department of Forest Resources, University of Minnesota-Twin Cities, 1530 North Cleveland Avenue, St. Paul, Minnesota 55108 USA.
}

The focus of this study is the origin and maintenance of patches in a cold-temperate conifer-hardwood forest. Patches in temperate forests are often caused by abiotic factors, such as catastrophic fires, that are influenced by topography and soils (Heinselman 1973, Yarie 1981, Hemstrom and Franklin 1982, Romme 1982, Cogbill 1985). In the hardwood-conifer forest region, patchiness is also attributed to differences in soils, nutrient status, topographical factors (Hough and Forbes 1943, Curtis 1959, Pastor et al. 1984, Spies and Barnes 1985, Whitney 1986), and wind (Hough and Forbes 1943, Henry and Swan 1974, Sprugel 1976, Foster $1988 a, b$ ).

Competitive interactions are responsible for patch formation in temperate forests with clonal or rootsprouting species, e.g., aspen (Barrett 1962) and beech (Hough and Forbes 1943). However, the role of competition in patch formation when no root-sprouting species are present, is relatively unknown. Many studies on competition in temperate forests focus on treeby-tree replacement processes (Horn 1971, Forcier 1975, Fox 1977, Runkle 1981, 1982, Woods and Whittaker 1981), response to management (Oliver and Stephens 1977, Lorimer 1983a), or growth rates of trees (Buchman et al. 1983, Lorimer 1983b). These studies have generally been used to predict changes in average 
species composition of a stand, rather than spatial separation of patches with unique species composition.

The presettlement mesic forests of our Upper Michigan study area were a patchy mosaic of stands dominated by either sugar maple (Acer saccharum Marsh.), hemlock (Tsuga canadensis (L.) Carr.), or a mixture of the two (Bourdo 1956, Pastor and Broshardt 1990; see Fig. 1). Both of these species are shade tolerant, and no canopy disturbance is required for seedling establishment. Hemlock entered the region $\approx 3000 \mathrm{yr} \mathrm{BP}$ (Davis et al. 1986), invading preexisting white pine and hardwood forests as the climate of the Upper Midwest has become cooler and wetter (Davis 1987). Pines are a minor component of the forest today. Catastrophic disturbances are rare in the region, occurring less than once every $1200 \mathrm{yr}$ at a given location (Canham and Loucks 1984, Frelich and Lorimer 1991). Thus, several generations of trees pass between catastrophes, unlike other northern temperate forests where the average period between catastrophes is about the same as tree longevity (Heinselman 1973). There should be ample opportunity for competitive interactions to influence the patch structure of the landscape.

The objectives of this paper are to (1) examine the species composition and spatial patterns of a stemmapped area of primary forest within Sylvania Wilderness Area in western Upper Michigan, (2) use spatial analyses to infer patterns of competition and assess whether or not species composition of each patch is self reinforcing, and (3) develop a simple model to determine if competition may explain patch formation.

\section{Hypotheses of patch formation}

The following are what we consider the four most reasonable hypotheses (not mutually exclusive) to explain the formation, maintenance, and breakup of patches within our 7.2 ha study area.

1) Soils and Topography Hypothesis. Patches with different species composition are located on soils with different parent materials, which may also correspond to topographical features. Differences in water-holding capacity, drainage, and nutrient supply severely limit growth of some species but not others. Location of patches would be fixed unless long-term soil development occurred or climate change overrode soil differences.

2) Disturbance History Hypothesis. The landscape is a mosaic of patches in different stages of succession following disturbance. Disturbances of different types could favor pulses of recruitment of either hemlock or sugar maple. Patch boundaries are not fixed because other disturbances with different orientations will eventually hit the area.

3) Competitive Interaction Hypothesis. Sugar maple and hemlock create seedbed or other microsite conditions that affect establishment, and therefore abundance nearby, of the other species. We recognize four types of interactions as subhypotheses; 3a) Negative reciprocal association. Each species has a negative effect on establishment of the other species, so that dead trees are usually replaced by the same species. This relationship could lead to monospecific clumps or patches that grow in size over time. Patch boundaries could fluctuate due to chance events or changes in climate that alter the competitive balance.

3b) Positive reciprocal association. Each species favors reproduction of the other more than itself, leading to long-term maintenance of mixed-species composition and the breakup of patches (Connell et al. 1984).

3c) Neutral association. Each species has a neutral effect on establishment of the other, with the same general results as $3 b$.

3d) One-way association. One species has a more positive or negative effect on establishment of the second species than the second species has on itself, leading to successional replacement.

4) Pattern of Invasion Hypothesis. Hemlock invaded preexisting hardwood forests, forming centers of infection $\approx 3000$ yr BP. Hemlock has not had time to spread from the initial invasion sites and dominate all of the forest. Therefore, the current pattern of patches still reflects the initial invasion pattern.

\section{STUdy AREA}

The study was conducted on a 7.2 ha study area within Sylvania Wilderness Area, Ottawa National Forest, located in Western Upper Michigan $\left(46^{\circ} 13^{\prime} \mathrm{N}\right.$, $89^{\circ} 18^{\prime}$ E; Fig. 1). Sylvania contains $\approx 6000$ ha of primary forest in one large block (Frelich and Lorimer 1991). The principal vegetation type in Sylvania, including the study area, is northern mesic forest, as defined by Curtis (1959). The most abundant hardwoods in Sylvania are sugar maple, basswood (Tilia americana L.), yellow birch (Betula alleghaniensis Britt.), and red maple (Acer rubrum L.). Conifers include hemlock, white pine (Pinus strobus), and white cedar (Thuja occidentalis). The study area was chosen to contain a diverse array of forest types and includes portions of hardwood, conifer, and mixed patches and a swamp. Some medium-sized white pine and white cedar trees were removed from the swamp in the southeast corner of the study area between 1920 and 1940 (Peacock 1986). The stumps are still readily visible after 50-70 yr.

Topography in Sylvania consists of hummocky moraine and outwash with many small lakes and bogs at an elevation of 500-550 m. Drift is deep (>30 m) and sandy loam in texture (Jordan 1973). The study area is several hundred meters from the nearest lake and has $\approx 22 \mathrm{~m}$ of relief, with several small hills and seasonally flooded swales. The upland soils are podzolic and are classified as Fragiorthods, with moderately developed clay fragipans at depths of $50-110 \mathrm{~cm}$, or Spodic 


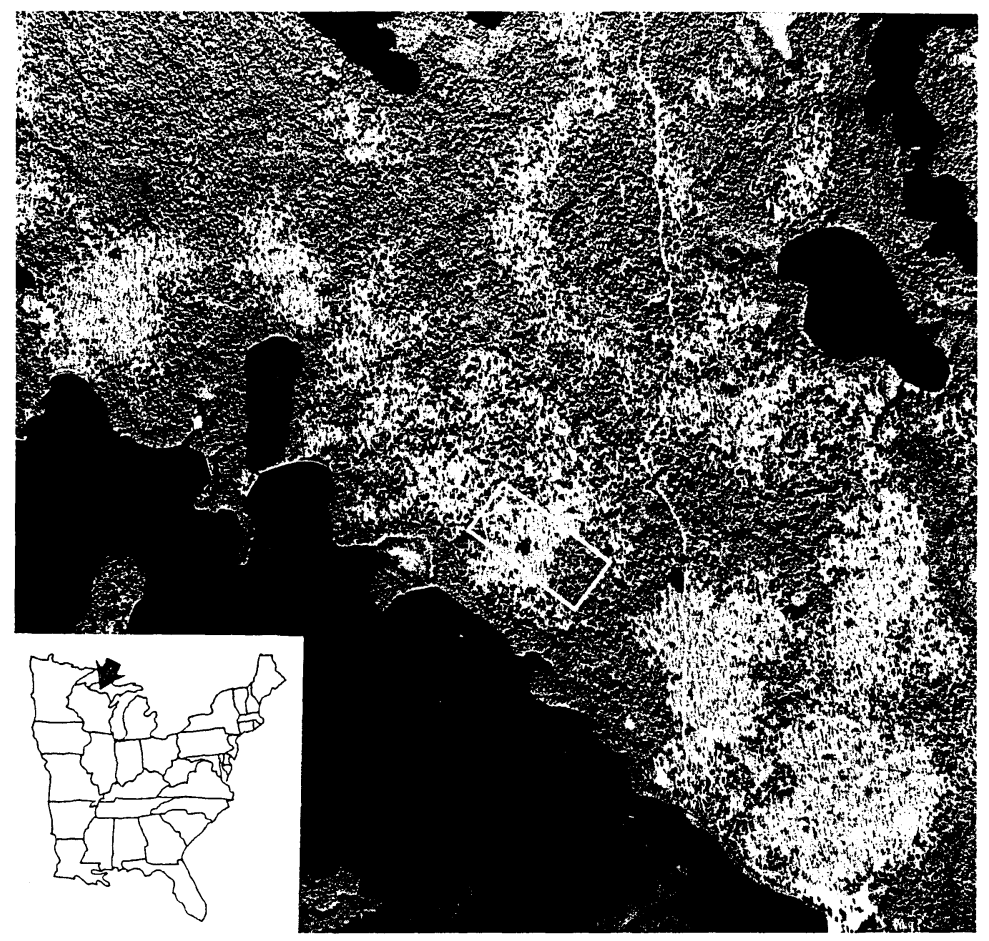

Fig. 1. Leaf-off infra-red air photo of Sylvania landscape. Conifer patches, mainly hemlock (in uplands), and spruce (in lowlands) are dark; hardwood patches dominated by sugar maple are light. White box outlines study area.

Udipsamments without a fragipan (Jordan 1973). Lowland soils are either mucky peats (Borohemists) or saturated mineral soils (Aquents).

The climate of the area is humid continental. Summers are short and cool; average frost-free season is $\approx 90 \mathrm{~d}$ (Phillips and McCulloch 1972) and average July temperature is $\approx 19.8^{\circ} \mathrm{C}$. Winters are long and cold; average January temperature is $-10.9^{\circ} \mathrm{C}$ (NOAA $1980 a, b$ ). Annual precipitation averages $\approx 85 \mathrm{~cm}$ and is fairly evenly distributed throughout the year (Court 1974).

\section{FIELD METHODS}

During 1987 and 1988 trees were mapped in a rectangular study area $140 \times 370 \mathrm{~m}(5.2 \mathrm{ha}) . x$ and $y$ coordinates of trees were measured within $20 \times 20 \mathrm{~m}$ grid squares with fiberglass tapes. The $x$ and $y$ coordinates obtained with this system are generally within $0.5 \mathrm{~m}$ of the true position relative to the corners of each 20-m grid square. In mid-1988, a Topcon surveying station was used to map an additional 2.0 ha, bringing the total size to $180 \times 400 \mathrm{~m}$ (7.2 ha). The $x$ and $y$ coordinates of the original grid were corrected to align with true compass direction. Elevations were taken at 727 points for topographical analysis.

All trees $>3.0 \mathrm{~cm}$ dbh (diameter at breast height, 6160 trees) were mapped, numbered, and species and $\mathrm{dbh}$ were recorded. Crown class was recorded as either overstory, those trees receiving direct sunlight from above, including saplings in gaps, or understory, those trees receiving no direct sunlight from above.

A soil pit was dug to a depth penetrating the $\mathrm{C}$ horizon every $20 \mathrm{~m}$ along a transect perpendicular to the edge of the hemlock and hardwood stands (Fig. 2). The depth and pedological characteristics of each horizon were described. Characteristics include color, texture, structure, abundance of roots and clasts, and nature of the lower boundary (Soil Survey Staff 1951).

\section{Data Analysis \\ Community types}

A representative area, referred to as a stand, containing 800-1000 trees was chosen within each of four community types on the study area (Fig. 2). The hardwood, mixed, and hemlock stands were chosen because they are relatively homogeneous. The swamp was outlined based on the distribution of red maple.

\section{Spatial patterns}

Formulas given in Sokal and Oden (1978) for spatial autocorrelation with categorical data were used to analyze spatial relationships between pairs of species. In the analysis, all pairs of trees within a given distance class are linked. The formulas in Sokal and Oden (1978) were used to calculate the expected number and variance of linkages if the trees were randomly distributed. If the number of observed linkages is sig- 

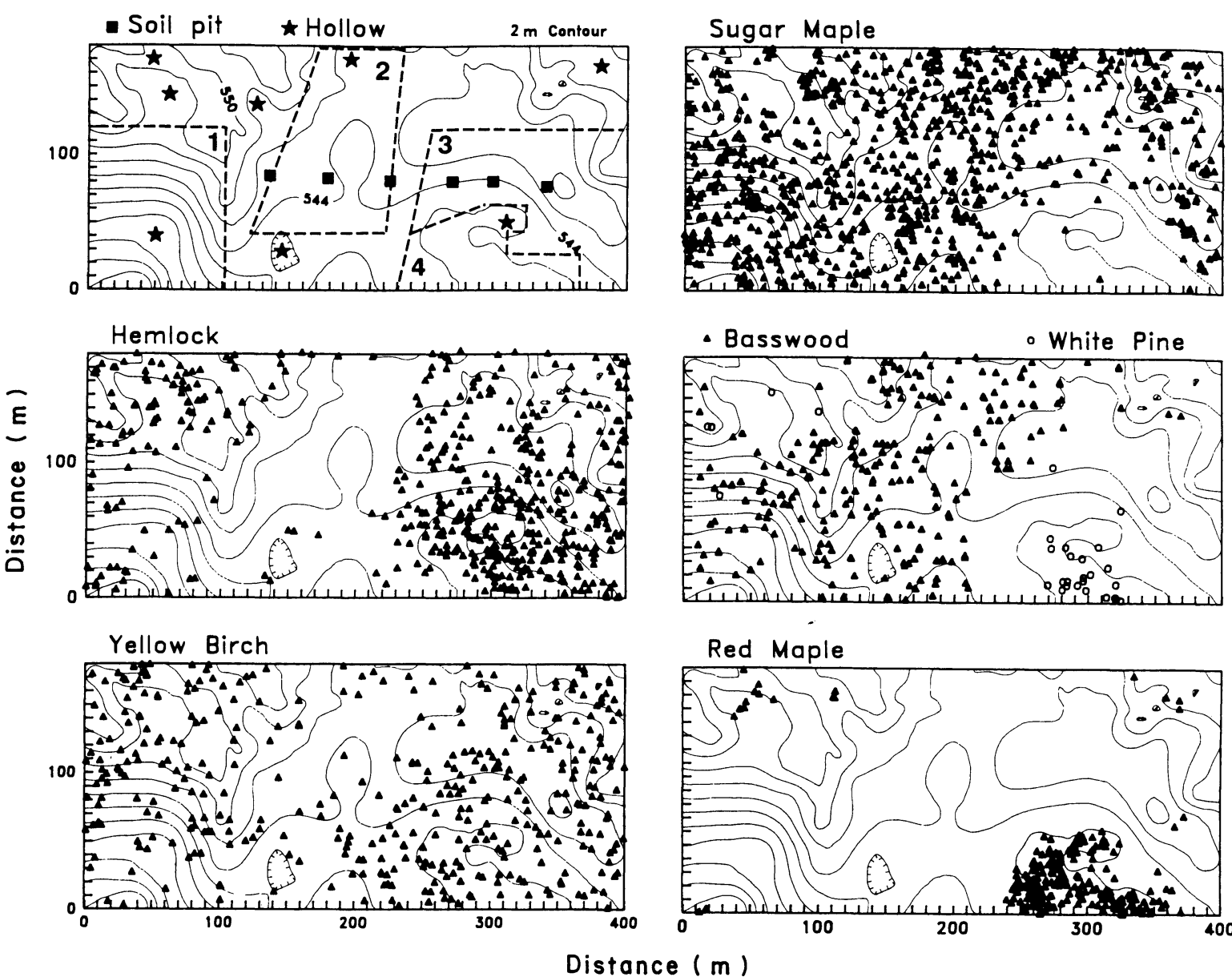

FIG. 2. Locations (upper left map) of four community stands studied in detail (1, mixed; 2, hardwood; 3, hemlock; 4, swamp), soil pits $(\square)$, and wet hollows $(\star)$. Other maps show distribution of overstory trees of major species.

nificantly greater or less than the expected number, then there is evidence of clumping or overdispersion.

Standard normal deviates (SNDs, distances from the mean in units of $\sigma$ ) were calculated for each distance class. SNDs $>1.96$ indicate clumping (within one species) or association (between two types of trees) that is significant at the $95 \%$ level. SNDs $<-1.96$ indicate significant overdispersion or negative association. Nonsignificant SNDs indicate random spatial patterns or no association.

Plots showing SND vs. distance classes are referred to as correlograms. If a correlogram shows a significant positive SND for sugar maple at, say $30 \mathrm{~m}$, this implies that there are more sugar maples $30 \mathrm{~m}$ distant from one another than there would be if sugar maples were distributed at random. To make inferences (average patch size, etc.) from correlograms, one assumes that the patch structure is the same throughout the area under analysis, an assumption that is true within the four communities, but not over the entire study area.

To analyze large-scale patchiness on the entire 7.2ha stem map, correlograms were prepared for canopy trees at $10.0-\mathrm{m}$ distance classes $(0-9.9 \mathrm{~m}$, etc.), to 120 $\mathrm{m}$. Small-scale patchiness within the hardwood, mixed, and hemlock stands, was examined at 4-m distance classes (0-3.9 m, etc.) to $40 \mathrm{~m}$, and 2-m distance classes (0-1.9 m, etc.) for the swamp, which has greater stem density and a finer scale spatial pattern than the other communities.

Spatial autocorrelation was also used to examine overstory-understory associations on each of the four community stands. For each species pair, autocorrelation SNDs between overstory trees of one species and understory trees of the other (and vice versa), were calculated for a close distance class $(0-3.9 \mathrm{~m})$. This association analysis was used to distinguish among the subhypotheses 3a-3d (Introduction: Hypotheses of patch formation). For example, if understory trees of two species are both positively associated with canopy trees of the opposite species, then positive reciprocal association (Hypothesis 3b), is taking place. Reciprocal replacement would occur if the reciprocal association continued over a long time.

Effects of neighborhood overstory composition on 
abundance of sugar maple and hemlock understory saplings were examined on 38 subplots, randomly located to include a wide range of overstory composition. A $10 \mathrm{~m}$ radius was chosen for the local neighborhood within which overstory species composition influences understory composition and transition probabilities. Ten metres is reasonably scaled for these forests (containing on average 12 trees), is close to the optimal radius for prediction of competitive effects recommended by Lorimer (1983b), and has yielded good empirical results in other tree-replacement studies (e.g., Woods and Whittaker 1981). Proportion of overstory trees of hemlock or sugar maple was used as a predictor of proportion of understory trees of the same species in a standard least squares regression.

\section{Structure of the MOSAIC simulation}

The MOSAIC simulation was designed to examine the long-term (millennial) effects of tree-by-tree replacement processes on spatial patterns in a forest. It is similar to a Markov model (e.g., Waggoner and Stephens 1970, Horn 1971, Runkle 1981), except that individual trees are mapped in two-dimensional space and transition probabilities are dependent on the species composition of a local neighborhood ( $10 \mathrm{~m}$ radius, same as the 38 subplots used to obtain empirical data) surrounding each tree. Analogous with the traditional Markov model, transition probabilities remain constant over time if given the same neighborhood conditions. Interesting dynamics of local patch formation may occur, depending on whether canopy trees of one species have a negative, neutral, or positive effect on nearby establishment of understory trees of other species.

The version of MOSAIC used in this study was constructed with the fewest possible assumptions. The plots were square, 16 ha in size, and had a canopy-tree density similar to the actual stem map, 400 canopy trees/ha. To simplify interpretation of the simulation, dynamics were examined between the two dominant species, sugar maple and hemlock. The trees began with a realistic age distribution, based on radial increment analysis of trees in nearby old-growth forests (Lorimer and Frelich 1989).

The model was run for $3000 \mathrm{yr}$, the length of time the sugar maple-hemlock forest mixture has been in existence, by 10 -yr time steps. Three events occur at each time step.

1) The probability of death is determined individually for each tree. Distribution of age at death was based on analysis of radial increment patterns from recently fallen trees in northern Michigan (Lorimer and Frelich 1989). Average age at death was $145 \mathrm{yr}$ for sugar maple and $195 \mathrm{yr}$ for hemlock. Mortality was negligible among young canopy trees, $2.5 \%$ /decade for middle-aged (70-100 yr old) trees and 10\%/decade for trees older than the mean age at death. Exogenous dis- turbance causing episodic recruitment of cohorts was not simulated.

2) A new canopy tree is recruited to replace each dead tree. The new tree is placed on the stem map randomly within a $4 \mathrm{~m}$ radius of the dying tree. The species of a new recruit depends on the species composition of the local neighborhood. Because the association analysis revealed a negative reciprocal relationship (see Results), the probability that a new tree in the simulation was either sugar maple or hemlock, was equal to the species proportions within a $10 \mathrm{~m}$ radius of the dying tree. For example, if 0.30 of the stems within $10 \mathrm{~m}$ of a dying tree were hemlock, then there was a $30 \%$ chance the replacement tree would be hemlock.

3) The age of all trees is increased by $10 \mathrm{yr}$, in preparation for step (1) above.

\section{RESULTS}

\section{Composition of the four communities}

The hardwood, mixed, and hemlock stands (Fig. 2) are samples along a continuum of hemlock vs. sugar maple dominance. Hemlock density is inversely proportional to sugar maple; the overstory sum of the two species only varies from 62.6 to $69 \%$ among the three communities, although sugar maple density ranges from 23 to $63 \%$ (Table 1). Basswood is distributed proportionally to sugar maple, and yellow birch proportionally to hemlock. The two shade-tolerant dominant species (sugar maple and hemlock) compose most of the understory. The swamp is the only community with significant representation of red maple and white pine (Table 1).

\section{Species distribution on the study area}

Canopy trees of all major dominant species show significant clustering at some spatial scale (Figs. 2 and 3). The patchiness of the landscape (Fig. 1) is reflected in significant clustering of the dominant species at long distances (40 to $>120 \mathrm{~m}$; Fig. 3). Our data do not provide average patch characteristics at this coarse scale, since the study area does not contain complete patches. However, the gradual descent of upland species SNDs from highly positive to negative with increasing distance (e.g., hemlock and sugar maple; Fig. 3), suggests that the degree of homogeneity of forest composition decreases gradually. The same phenomenon occurs in the swamp. The SNDs for red maple and white pine, both swamp dominants, fall to a nonsignificant level by 85 and $55 \mathrm{~m}$, respectively. This is because most of the white pine are concentrated in the center of the swamp, while red maple grows in the center and peripheral parts of the swamp. Thus, species have different distributions of abundance along the wet-to-mesic gradient. Patches are intergrading, with boundaries of varying sharpness, rather than discrete with uniform composition within. 
TABLE 1. Relative stem density of component tree species in the overstory and understory of the four communities.

\begin{tabular}{|c|c|c|c|c|c|c|c|c|}
\hline \multirow[b]{3}{*}{ Species } & \multicolumn{8}{|c|}{ Stand } \\
\hline & \multicolumn{2}{|c|}{ Hardwood } & \multicolumn{2}{|c|}{ Mixed } & \multicolumn{2}{|c|}{ Hemlock } & \multicolumn{2}{|c|}{ Swamp } \\
\hline & Over & Under & Over & Under & Over & Under & Over & Under \\
\hline & \multicolumn{8}{|c|}{ Percent of total stems } \\
\hline Sugar maple & 63.0 & 83.8 & 53.5 & 81.5 & 23.0 & 48.7 & 0.5 & 1.6 \\
\hline Hemlock & 1.6 & 1.4 & 9.1 & 7.5 & 46.0 & 36.9 & 22.5 & 28.5 \\
\hline Yellow birch & 8.0 & 2.1 & 13.1 & 0.7 & 22.1 & 2.4 & 10.1 & 4.3 \\
\hline Basswood & 22.0 & 1.1 & 17.7 & 2.3 & 0.7 & $\cdots$ & $\cdots$ & $\ldots$ \\
\hline Red maple & 0.3 & $\ldots$ & 0.5 & $\ldots$ & 2.7 & 1.4 & 53.3 & 53.2 \\
\hline Ironwood & 4.0 & 10.5 & 1.7 & 5.2 & $\cdots$ & 0.5 & $\cdots$ & $\cdots$ \\
\hline White pine & $\cdots$ & $\ldots$ & 0.3 & $\cdots$ & 0.5 & $\cdots$ & 4.7 & 1.6 \\
\hline White cedar & $\ldots$ & $\ldots$ & 1.0 & $\cdots$ & 2.5 & 4.1 & 1.4 & 1.3 \\
\hline Balsam fir & $\cdots$ & 0.5 & 2.0 & 2.3 & 2.7 & 5.8 & 2.0 & 6.7 \\
\hline Other & 1.1 & 0.6 & $\cdots$ & 0.5 & $\cdots$ & 0.1 & 5.5 & 2.8 \\
\hline Total trees & 373 & 560 & 406 & 561 & 444 & 417 & 445 & 372 \\
\hline
\end{tabular}

Within-community spatial patterns are different than across the entire study area. On upland sites hemlock and sugar maple, the two major dominants, show no clustering in the mixed and hardwood communities, but sugar maple shows clustering at the $0-12 \mathrm{~m}$ scale in the hemlock community (Fig. 4).

\section{Soils and topography}

The soil profiles revealed fairly uniform spodosols across the transect between the hemlock and hardwood dominated patches. The upper $5-10 \mathrm{~cm}$ of humus overlay a pinkish-gray sandy loam $\mathrm{E}$ (eluvial) horizon, which in turn lay over a reddish-brown loam to loamy-sand $\mathrm{B}$ (spodic) horizon extending down 30 to $40 \mathrm{~cm}$. Below this, a massive fragipan of sandy texture was uniformly encountered both in the pits and in exploratory coring with a soil auger in the area of each pit. The pan was uniformly $40 \mathrm{~cm}$ thick and overlay a light reddishbrown sandy $C$ horizon.

GIS (Geographic Information System) analysis of topography on the study area reveals no division of species by aspect. For example, 68.7 and $62.3 \%$ of the surface area within the hemlock and hardwood stands, respectively, is on relatively warm and sunny aspects (southeast-west). All aspects occur within each of the three upland community types, and their boundaries do not correspond to contour lines (Fig. 2).

\section{Patterns of association}

There are 17 complete species-pair relationships among the four communities (Table 2). Following the hypotheses 3a-3d (Introduction: Hypotheses of patch

TABLE 2. Patterns of association between overstory trees and understory saplings using associations as defined in Introduction: Hypotheses of patch formation. Associations are based on significant ( $>95 \%)$ spatial autocorrelation at the 0-3.9 $\mathrm{m}$ distance class. Blank indicates insufficient number of stems for conclusion about association.

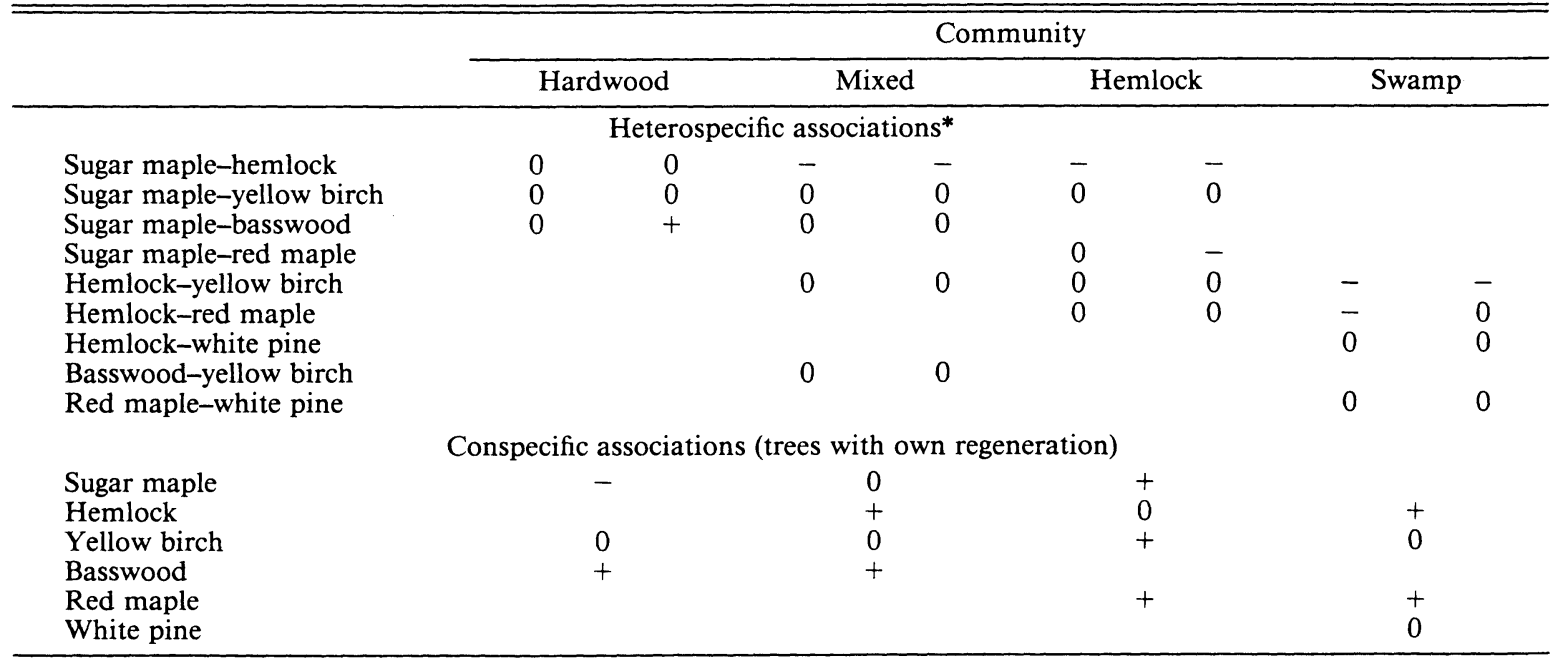

* Negative reciprocal $(--)$, positive reciprocal $(++)$, neutral $(00)$, one way $(+0,0-$, etc. $)$. For example: $(0+)$, for the sugar maple-basswood pair, means that sugar maple canopy trees have a neutral effect on abundance of understory basswood, but basswood canopy trees have a positive effect on abundance of sugar maple understory saplings. 
formation), 11 of the 17 exhibit neutral association, where neither species significantly affects understory abundance of the other. Three species pairs exhibit negative reciprocal association, and three one-way association. None of the species pairs exhibit positive reciprocal association.

There are some differences in spatial pattern and type of association between species pairs among the four communities. For example, sugar maple and hemlock have a neutral association in the hardwood community, but negative reciprocal association in the mixed and hemlock communities. Similarly, hemlock and yellow birch have neutral association in the mixed and hemlock community, but negative reciprocal association in the swamp. Both sugar maple and yellow birch have a positive association with their own reproduction in the hemlock community, but not elsewhere (Table 2).

\section{Relationship between sugar maple and hemlock}

Results of the MOSAIC simulation depend on using the correct relationship between sugar maple and hemlock. Table 2 indicates a negative reciprocal relationship between these two species. The data from the 38 subplots ( $10 \mathrm{~m}$ radius) confirm the negative reciprocal

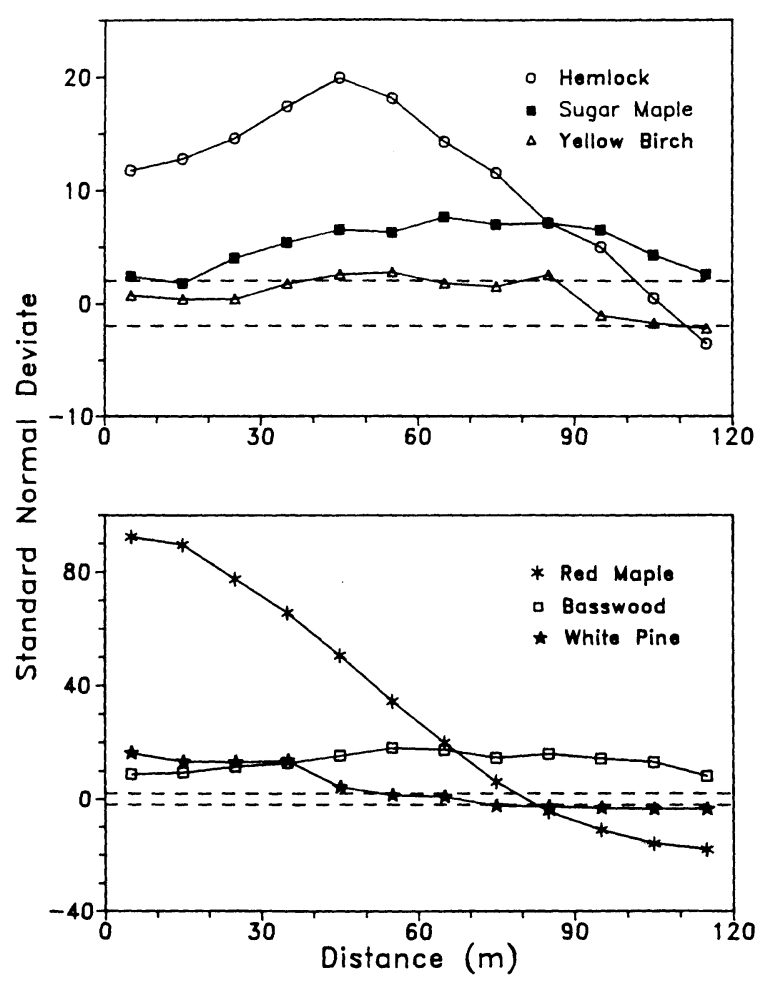

FIG. 3. Correlograms of overstory trees of selected species on the entire 7.2 ha study area. Dashed lines demark zone of nonsignificance $(<2$ standard deviations from zero correlation). Significant positive SND indicates clumping, significant negative SND indicates overdispersion.
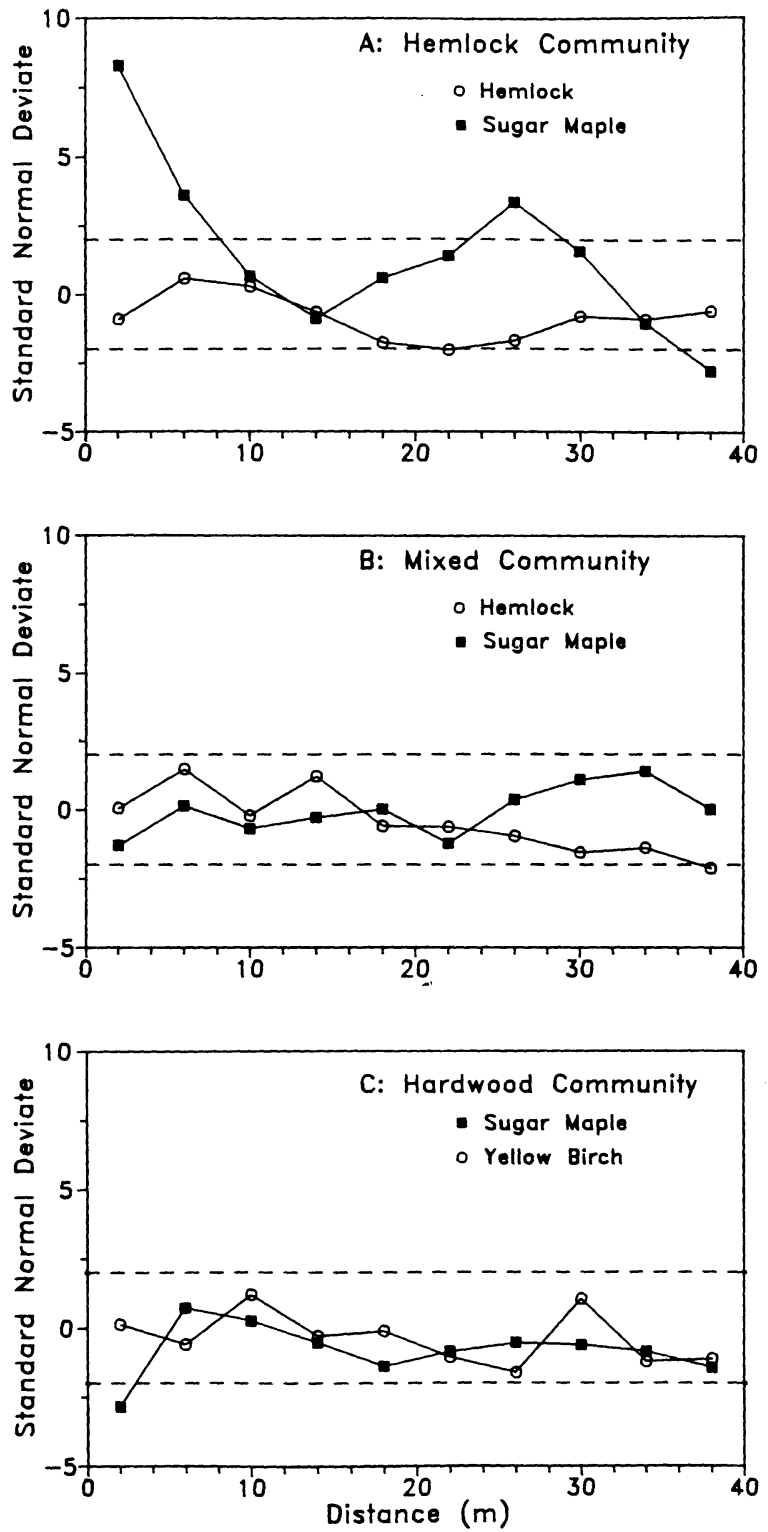

FIG. 4. Correlograms for overstory trees of selected species within communities. (A) Hemlock community. (B) Mixed community. (C) Hardwood community.

association; abundance ratio of hemlock overstory trees and hemlock understory saplings from the subplots is approximately $1: 1$. The relationship has an $r^{2}$ of $73.8 \%$ (Fig. 5A). Results for sugar maple are nearly identical (Fig. 5B). Therefore, the rules of replacement used in MOSAIC, i.e., probability of replacement of a dying overstory tree being proportional to neighborhood species composition, seem reasonable. The rules of replacement are confirmed by two types of data, association analysis looking at the frequency with which stems of a given species are located near other stems of the same species, and actual stem counts from a randomly chosen series of subplots. 

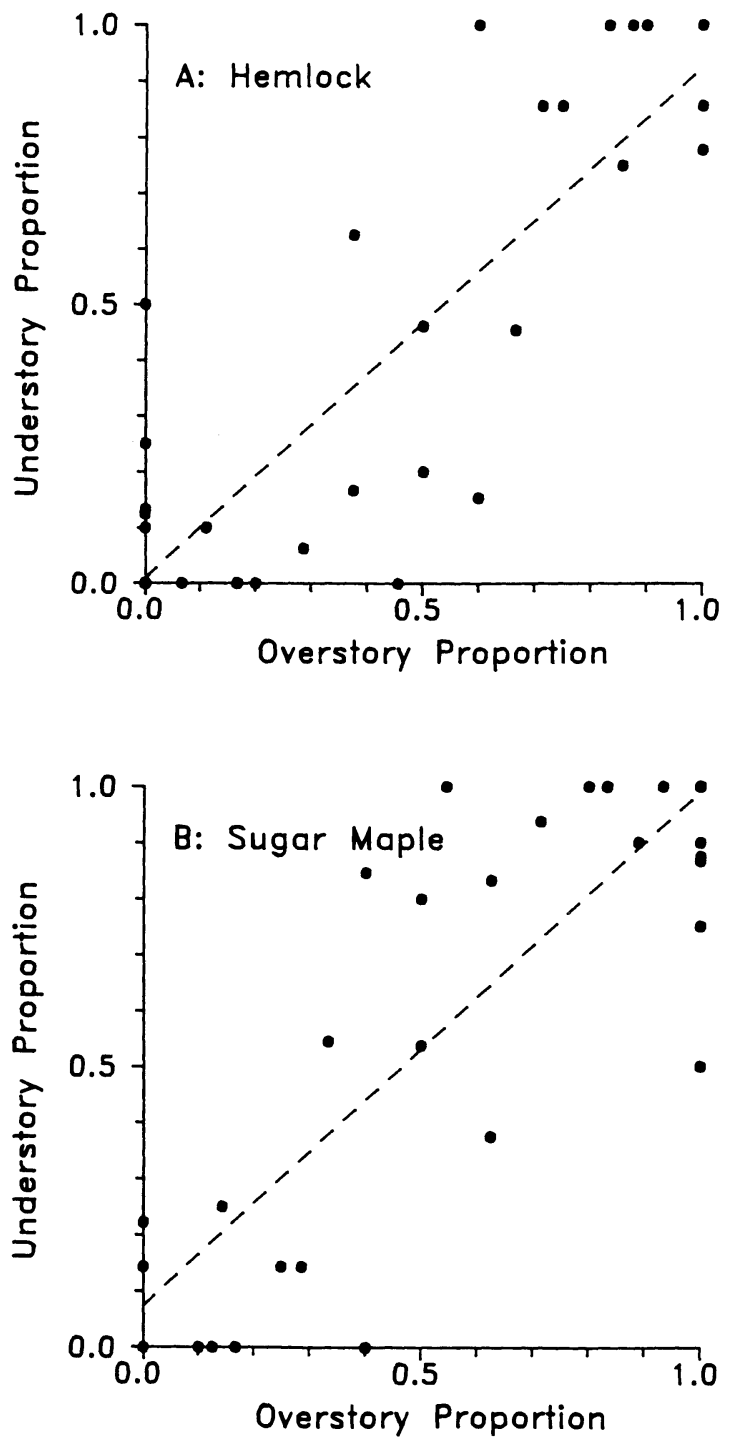

FIG. 5. Overstory-understory relationship between sugar maple and hemlock. (A) Hemlock overstory-tree abundance as a predictor of hemlock understory-tree abundance. (B) Sugar maple overstory-tree abundance as a predictor of sugar maple understory-tree abundance.

\section{MOSAIC simulation}

MOSAIC experiment number 1.- The purpose of this experiment is to test whether or not a patchy landscape can develop from mixed-species stands. Simulation begins with an equal number of randomly mixed sugar maple and hemlock trees. The flat correlogram for initial conditions (Fig. 6) confirms that the initial mix is random. After $3000 \mathrm{yr}$, small single-species groups of trees that occurred by chance initially have magnified to become major patches on the landscape (Fig. 7). Spatial autocorrelation analysis reveals significant clustering of both sugar maple and hemlock, at distances up to $60 \mathrm{~m}$ (Fig. 6). The patch structure is similar to, but not as pronounced as the study area (cf. Figs. 3 and 6). Experiment number 1 was run sev. eral times, and each time a patchy landscape pattern developed.

In all MOSAIC experiments, hemlock slowly in. creased its importance relative to sugar maple, even though the same replacement rules were used. This is because hemlock has an average canopy residence time longer than sugar maple ( $195 \mathrm{vs.} 145 \mathrm{yr}$ ). In experiment number 1, the original 3200 hemlocks increased to 4198 over $3000 \mathrm{yr}$.

MOSAIC experiment number 2. - Simulation begins with an all-sugar maple forest. To simulate random invasion, hemlock was allowed a $1 \%$ probability of
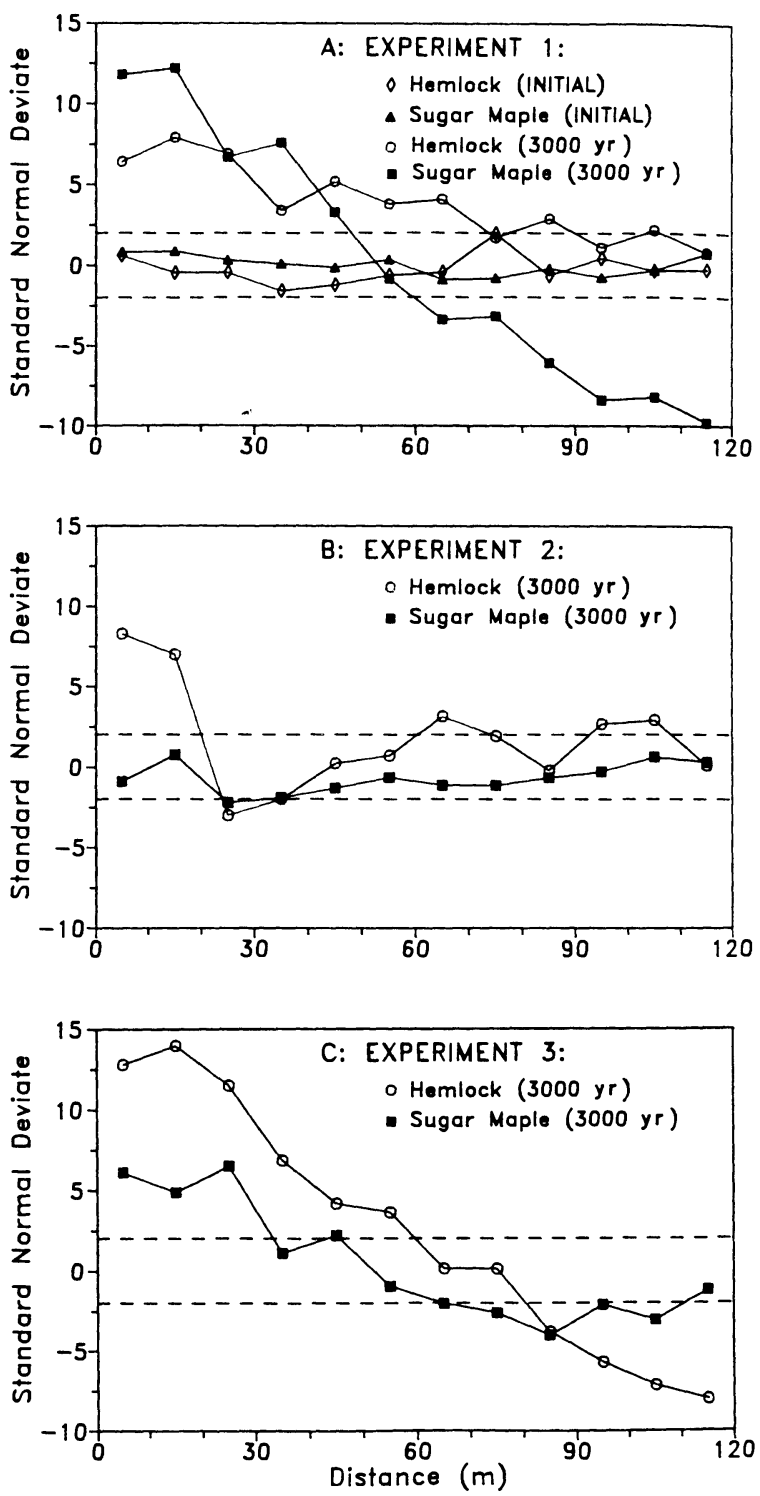

FIG. 6. Correlograms for MOSAIC simulation experiments, each of which began with a mixed-species stand. (A) Experiment number 1. (B) Experiment number 2, and (C) Experiment number 3 . 
A) Initial Maple Distribution

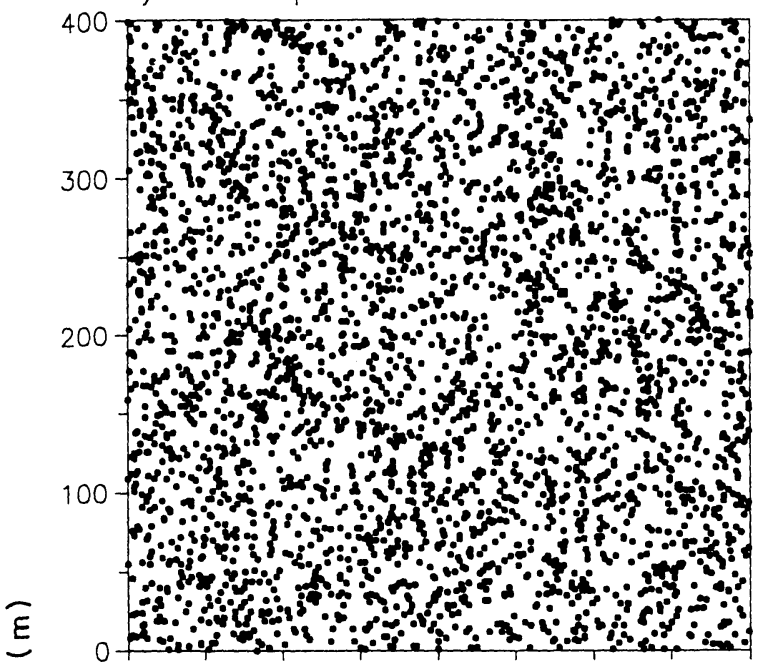

C) Maple after $3000 \mathrm{yr}$

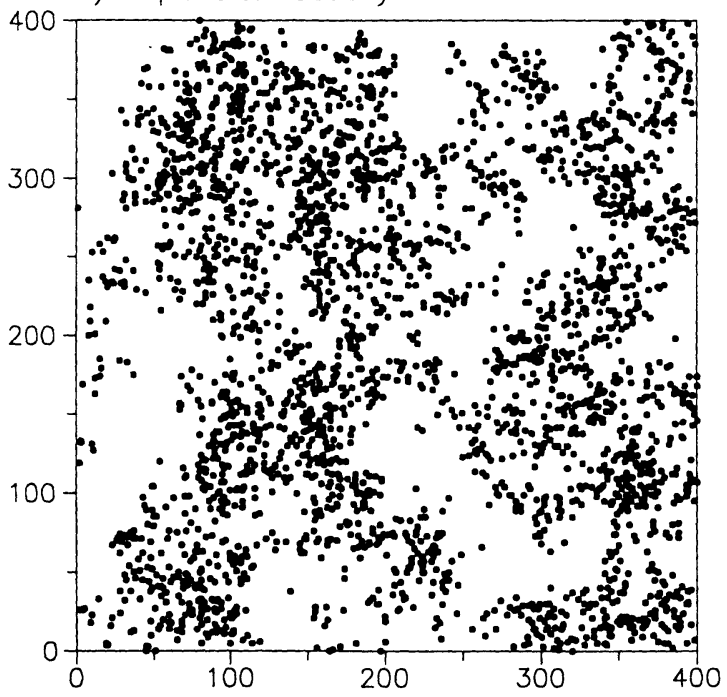

B) Initial Hemlock Distribution

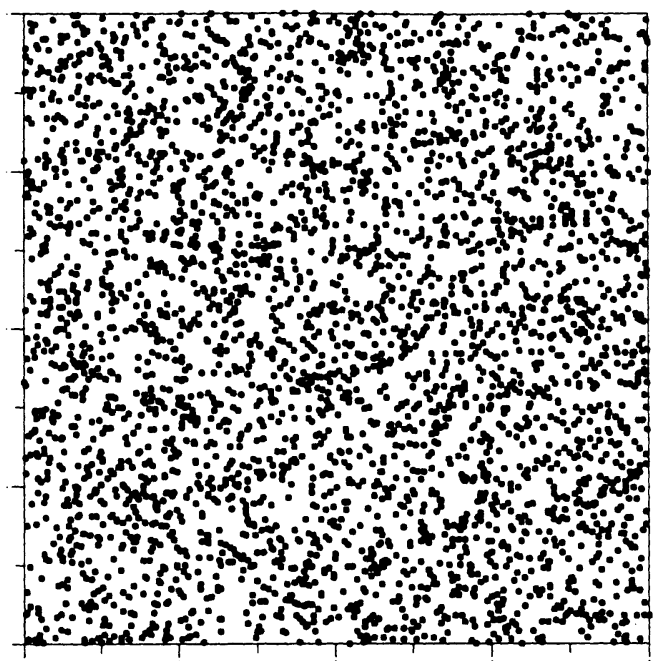

D) Hemlock after $3000 \mathrm{yr}$

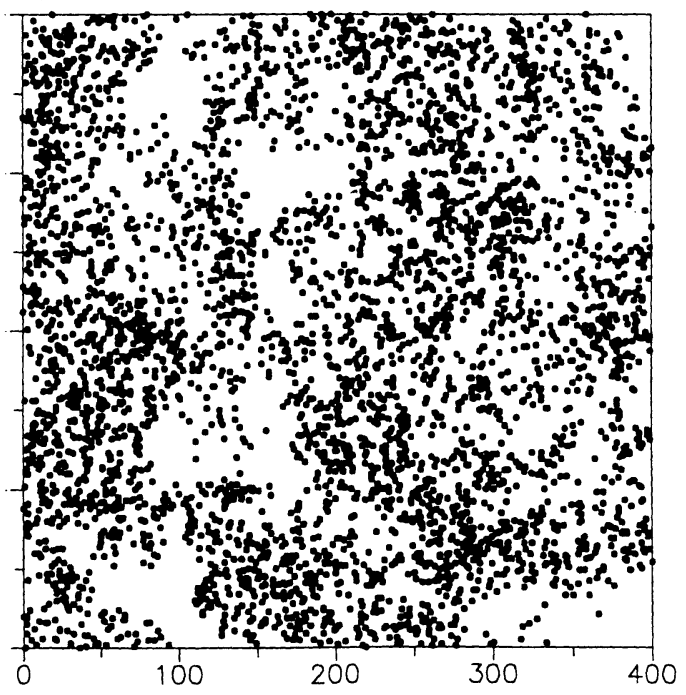

Distance $(\mathrm{m})$

FIG. 7. MOSAIC simulation stem maps for experiment number 1. (A) Initial sugar maple distribution. (B) Initial hemlock distribution. (C) Sugar maple distribution after 3000 yr. (D) Hemlock distribution after 3000 yr.

replacing a dying sugar maple, regardless of local species composition. The same rules of self replacement as in experiment number 1 were also applied. In the first $1000 \mathrm{yr}$ of simulation, there were random invasions and extinctions of hemlock. Eventually, the chance juxtaposition of $>1$ hemlock allowed clusters to start. By $3000 \mathrm{yr}$, hemlock clusters $>20 \mathrm{~m}$ in diameter formed (Figs. 6 and 8).

MOSAIC experiment number 3. - Simulation begins with three clusters of hemlock, each $20 \mathrm{~m}$ in diameter and the same replacement rules as experiment number 2. The purpose is to simulate invasion of hemlock into good microsites, followed by climate change that al- lows hemlock to grow anywhere on the plot. After 3000 $\mathrm{yr}$, the initial clusters have grown and become irregular in shape (Fig. 8), but not to the size of the clusters in experiment number 1 (cf. Fig. 7). This indicates that clustering occurs faster if there are many small, widespread centers of invasion, rather than a few large dense centers.

\section{Discussion}

\section{Patterns of association}

Sugar maple and hemlock. - At the spatial scale of the entire study area, sugar maple and hemlock show 


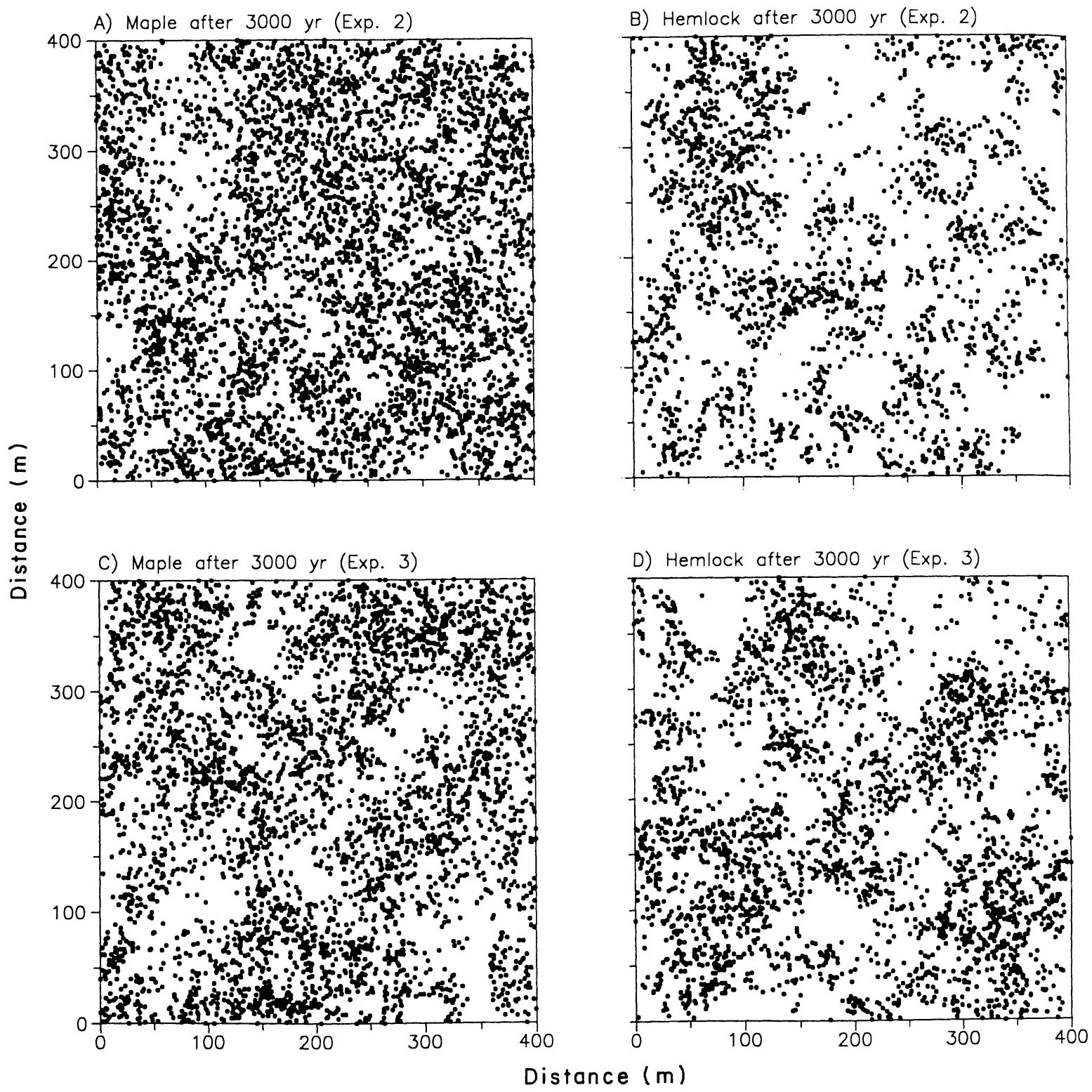

FIG. 8. Stem maps for MOSAIC experiment numbers 2 and 3. (A and B) Sugar maple and hemlock distribution for experiment number 2. (C and D) Sugar maple and hemlock distribution for experiment number 3.

negative association (Fig. 3). However, there are some differences in the relationship between these two species in each of the three upland communities, hemlock, mixed, and hardwood, where they are dominant. Within both the hemlock and mixed communities, sugar maple and hemlock exhibit negative reciprocal association, whereas in the hardwood community, although the sample size is small, hemlock and sugar maple exhibit a neutral relationship (Table 2). Questions arise such as: (1) how is sugar maple able to avoid the negative effects of hemlock within the hemlock community?, (2) how do the two species co-exist in the mixed community?, and (3) why is there a different relationship in the hardwood community?
Sugar maple could avoid the negative effects of hemlock within the hemlock community, if the community were actually a fine mosaic of small stands, rather than a "melting pot" mixture. Correlograms for canopy trees within the hemlock community reveal a strong negative association between sugar maple and hemlock at distances up to $12 \mathrm{~m}$, clustering of sugar maple with patch sizes of 8-12 $\mathrm{m}$, but no clustering of hemlock (Fig. 4). Sugar maple and other hardwoods have a positive association with their own understory saplings, but hemlock has a neutral effect on its own understory saplings (Table 2). All of these facts are consistent with small stands, or inclusions, of hardwoods within a hemlock matrix, as was suggested by a GIS analysis of 
the entire Sylvania landscape (Pastor and Broshardt 1990).

The co-existence of sugar maple and hemlock in the mixed community, however, is difficult to explain. The community is not a mosaic of small stands, because neither sugar maple nor hemlock canopy trees are clumped (Fig. 4). Yet the negative reciprocal association relationship between canopy and understory trees for both sugar maple and hemlock indicates that clumps should form. Either the mixed community is currently being invaded by hemlock, so that clumps are just beginning to develop (see Results: MOSAIC simulation), or it is part of a fluctuating border between the hardwood community and a hemlock community, which lies just outside the study area, but is similar to the hemlock community in the study area.

Some of the spatial characteristics of the mixed community are intermediate in nature. For example, sugar maple has positive, neutral, and negative associations with its own reproduction in the hemlock, mixed, and hardwood communities, respectively (Table 2). The hardwood stand has a carpet of sugar maple seedlings, which is slightly less dense under mature overstory trees, resulting in negative association, whereas in the hemlock stand, seedlings of all types are sparse, so that a few sugar maple seedlings under the clusters of overstory sugar maples result in positive association with their own seedlings.

The answer to the third question above, why the relationship between hemlock and sugar maple is neutral in the hardwood community, may be a densitythreshold effect. The hemlocks within the hardwood community are isolated trees (Fig. 2), and appear unable to substantially affect reproduction of sugar maple as they can at higher density within the mixed and hemlock communities (Table 2). The presence of a few hemlock in the hardwood community depends on the existence of special microhabitats, such as tip-up mounds and rotten logs, where the usual deleterious effects of sugar maple on the seedbed do not occur.

Other species. -Some of the one-way associations in Table 2 are of interest. In the hardwood community, sugar maple seedling density is positively correlated with the occurrence of basswood canopy trees. This suggests replacement of basswood by sugar maple. However, basswood has the compensating characteristic of stump sprouting. Basswood can maintain a presence in the hardwood community, possibly because of the superior growth of stump sprouts compared to sugar maple seedlings. Hemlock has a negative effect on red maple seedlings in the swamp (Table 2), suggesting replacement of red maple by hemlock. This is probably a postdisturbance successional sequence, because the red maples date from the time that conifers were removed from the swamp between 1920 and 1940 . Given that hemlock is much more shade tolerant than red maple, the one-way relationship is expected.

\section{Soils and topography hypothesis}

Of the four community types, only existence of the swamp, with its flat topography (Fig. 2) and organic soils is clearly explained by this hypothesis. The major division between hemlock and hardwood running northeast-southwest across the study area does not correspond to any topographical feature. In fact, topographical contour lines run perpendicular to the boundary (Fig. 2). This is consistent with results of Pastor and Broshardt (1990) that hemlock, mixed, and hardwood cover types in Sylvania as a whole are randomly distributed with respect to aspect.

The lack of major pedologic differences underlying the hardwood and hemlock communities is confirmed by a Sylvania soil map by Jordan (1973), which shows the uplands of the study area as one soil class, i.e., well drained to moderately well drained with coarse loamy textures and moderate fragipan. Other studies in the upper midwest have found spodosols or histosols under hemlock stands and alfisols under hardwoods (Milfred et al. 1967, Pastor et al. 1982), differences that would have been easy to detect in the current study. However, both sugar maple and hemlock can grow on a wide variety of soils from loamy sand to clay loam, and from spodosols to borofolists, which have no mineral soil at all (Frelich 1986). Clearly hemlock and sugar maple could each dominate the entire upland portion of the study area, if the other species was absent. Therefore, segregation of hemlock and sugar maple here does not seem to be due to pedologic processes. However, at this time, we do not have enough information to dismiss the possibility that differences in microbiology of litter decay reinforce the competitive advantage each species has on part of the study area (see Competitive interaction hypothesis: Mechanism of competitive interaction, below).

\section{Disturbance history hypothesis}

Disturbance history cannot be invoked to explain the species composition and boundaries of the hardwood, mixed, and hemlock communities. Tree ring analysis from 500 canopy trees (L. E. Frelich and L. J. Graumlich, unpublished manuscript) on the study area indicates similar rates of canopy recruitment in the hemlock and hardwood communities, and no catastrophic disturbances for the past $150 \mathrm{yr}$. Frelich and Lorimer (1991) also found little difference in the frequency of disturbances between hemlock and hardwood forests in the western Upper Michigan region. The disturbance regime in the hardwood-hemlock forests of the Upper Great Lakes is dominated by wind, which causes little change in species composition when the community dominants are shade-tolerant species with advance regeneration present (Frelich and Lorimer 1991).

Unlike wind, intense fires usually change species composition of stands. Fires in hardwood forests allow establishment of oak, pine, birch, or aspen groves 
(Hough and Forbes 1943, Buell et al. 1954, Henry and Swan 1974, Frelich 1986, Foster 1988a). Some forest patches in Sylvania are caused by fire. A narrow strip of paper birch-hemlock forest along the south shore of Crooked Lake in Sylvania contains many even-aged paper birch dating from $\approx 1904$, fire scars on larger trees that survived the fire, and abundant charcoal in the soil (L. E. Frelich, unpublished data). However, there is no such evidence of fire on the 7.2 ha study area.

\section{Competitive interaction hypothesis}

Evidence has been sparse that competition causes patch formation independent of soil boundaries or disturbances in temperate forests without root-sprouting species. Hibbs (1982) proposed that small patches of white pine are maintained within hardwood forests if pines near the edge of the patch buffer the central trees from competition by surrounding hardwoods. Balsam fir is able to form small patches within Wisconsin hardwood forests, because it invades bracken fern-grass-dominated openings unfavorable for hardwood establishment (Curtis 1959, Levy 1970, Dawes and Maravolo 1973).

It seems likely that competitive interactions between canopy and understory trees contribute to vegetation patchiness in Sylvania. In an area like Sylvania where disturbances do not cause change in species composition and the major (usually shade tolerant) species present have a negative reciprocal association, the landscape is likely to develop monodominant patches that grow in size over time. This pattern should develop whether the species start out mixed together, or one species invades a preexisting forest of another (e.g., Figs. 6-8). If the dominant species have a positive reciprocal or neutral relationship, a mixed stand should develop. An example is sugar maple and yellow birch (Table 2). If these two were the dominant species the landscape might be a random mixture without monodominant patches, as occurs within the hardwood stand (Fig. 4). Landscapes dominated by species with oneway relationships should be unstable and dependent on disturbance for maintenance of diversity, unless one species has a compensating characteristic, such as stump sprouting in basswood.

Mechanism of competitive interaction.-One hypothesis explaining the negative reciprocal association between sugar maple and hemlock in Sylvania concerns effects of mature trees on seedbed conditions. To avoid desiccation, hemlock seedling roots must reach a consistent moisture supply within a few centimetres of the surface shortly after germination (Graham 1941, Hough and Forbes 1943, Davis and Hart 1961, Fowells 1965). This is unlikely in the hardwood community, which has $5-10 \mathrm{~cm}$ of coarse leaf litter. Hemlock seedlings are often smothered during the first few years by leaf fall in hardwood forests (Fowells 1965). Microsites found in the hemlock community, such as well rotted conifer logs, or exposed mineral soil on tip-up mounds are the most likely places for successful hemlock establishment (Hough and Forbes 1943, Eyre and Zillgitt 1953, Goder 1955).

Sugar maple seedlings are able to penetrate thick, coarse duff, and are often found growing on undisturbed forest floor in hardwood forests (Curtis 1959, Beatty 1984). Intolerance of low nitrogen availability is thought to contribute to low growth of sugar maple under a hemlock canopy, where litter has high C:N ratios and relatively low $\mathrm{N}$ mineralization (Pastor et al. 1984, Mladenoff 1987).

If the seedbed mechanisms of competitive interaction between sugar maple and hemlock are correct, then the two-species association may be altered on other soils where seedbeds have different characteristics than our study area. For example, silt and clay soils in temperate climates often have much higher nitrogen mineralization capacity than the study area's sandy loam (Peet and Loucks 1977, Pastor et al. 1984). Leaf litter under hardwoods would decompose faster, duff would be thinner, and hemlock seedlings could be successful. Under a hemlock canopy, nitrogen mineralization on clay soils may be lower than hardwoods, but still above the threshold for good sugar maple seedling growth. With these conditions, we predict that the negative reciprocal association between sugar maple and hemlock observed in the current study would be replaced by a neutral or positive reciprocal association, and the landscape would not necessarily become patchy over time. Although no data set sufficient to test this prediction currently exists, some anecdotal evidence is available. A stand on clay loam soil, with thin duff and abundant hemlock seedlings under a sugar maple-dominated canopy, was documented by Frelich and Lorimer (1985), and Mladenoff (1987) found that nitrogen mineralization rates are relatively high in gaps formed by death of hemlock trees on silt loam soil. Both of these results suggest that positive reciprocal replacement between sugar maple and hemlock is possible.

\section{Pattern of invasion hypothesis}

The western expansion of hemlock's range over the past $3000-4000 \mathrm{yr}$ is believed to have been moisture limited (Bartlein et al. 1986), and corresponds with a regional increase of spruce and fir pollen interpreted as evidence for cooler/moister conditions (Davis 1987). Currently, hemlock is most abundant in a narrow band along Lake Superior (Frelich and Lorimer 1991), and in Sylvania, near bogs and other moist sites (LeebensMack 1989, Pastor and Broshardt 1990). These observations suggest that hemlock would have invaded around bogs first. It might then have been able to slowly invade upland maple forests, due to its longer life-span, as in MOSAIC experiment number 3. Although hemlock in the model has an opportunity to replace adjacent sugar maples every $145 \mathrm{yr}$, sugar maple only has the chance of replacing hemlock every $195 \mathrm{yr}$ on av- 
erage. A MOSAIC simulation beginning with the plot divided half and half between maple and hemlock, indicated that $2 \mathrm{~m} / 100 \mathrm{yr}$ is a reasonable rate of invasion. Thus, in the $3000 \mathrm{yr}$ since hemlock entered Sylvania, hemlock could have moved $\approx 60 \mathrm{~m}$ into uplands. In this scenario, hemlock would dominate areas where suitable bogs or hollows for initial hemlock establishment are $<120 \mathrm{~m}$ apart. Seventy-four percent of all canopy hemlock on the study area lie within 60 m of permanently wet hollows, while only $32 \%$ of sugar maple are similarly situated.

If hemlock has moved into uplands from wet microsites, the invading front has invaded all slopes, so that the modern distribution is independent of contour lines (Fig. 2). Thus, topography (hypothesis 1) may have initially influenced the distribution of hemlock during invasion $3000 \mathrm{yr}$ BP. A second feature of an invading front of hemlock is its irregular nature. Small interdigitating projections and irregular patches are likely to form due to random replacement events between sugar maple and hemlock (Fig. 8). The results of this are the mixed stands, which are parts of spatial continua of varying steepness (cf. Figs. 2, 6, 8) between monodominant sugar maple and hemlock patches.

In summary, hemlock may have invaded the study area first around the wet hollows, where establishment was relatively easy because of high moisture. After the initial invasion, overstory-understory interactions between sugar maple and hemlock and chance determined where in the uplands hemlock clumps formed and grew into large patches. Therefore, pattern of invasion and competitive interactions (hypotheses $3 \mathrm{a}$ and 4) together are the most reasonable explanation for the patchy distribution of hardwood, mixed, and hemlock communities on the Sylvania study area.

Implications of the MOSAIC model are that random invasion and extinction events, similar to those proposed by Hubbell and Foster (1986) as evidence of nonequilibrium species composition in a tropical forest, may operate in some temperate forests at small spatial scales (a few hectares). Such events maintain mixed stands along the boundaries of monodominant patches. Negative reciprocal association can result in a slowly shifting mosaic. Landscape properties may be maintained at large spatial scales, even as the individual patches change shape and size, similar to the intertidal "landscapes" of Paine and Levin (1981). If so, the shifting mosaic in some forests may be superimposed upon, and operate independently of, patches caused by disturbance. Finally, feedbacks from individual species on seedbeds, or possibly other microsite conditions, may scale up to the landscape level, and help determine the overall character of landscape patch distribution and dynamics.

\section{ACKNOWLEDGMENTS}

We gratefully acknowledge logistical support from R. Bodine and other staff members of Ottawa National Forest. K.
Beck, M. Broshardt, J. Ferrari, Zhou Guang, S. Hill, J. Leebens-Mack, W. Schwarz, K. Vogel, and C. Zabinski assisted with field work and data analysis. S. Sugita and two anonymous reviewers provided helpful suggestions on the manuscript. This research was supported by The Mellon Foundation, and by National Science Foundation Grants BSR 8615196 to M. B. Davis and J. Pastor, and BSR 89-16503 to M. B. Davis.

\section{Literature Cited}

Barrett, J. W. 1962. Regional silviculture of the United States. Ronald Press, New York, New York, USA.

Bartlein, P. J., I. C. Prentice, and T. Webb III. 1986. Climatic response surfaces from pollen data for some eastern North American taxa. Journal of Biogeography 13:35-57.

Beatty, S. W. 1984. Influence of microtopography and canopy species on spatial patterns of forest understory plants. Ecology 65:1406-1419.

Belsky, A. J. 1986. Population and community processes in a mosaic grassland in the Serengeti, Tanzania. Journal of Ecology 74:841-856.

Bourdo, E. A. 1956. A review of the General Land Office Survey and of its use in quantitative studies of former forests. Ecology 37:754-768.

Buchman, R. G., S. P. Pederson, and N. R. Walters. 1983. A tree survival model with applications to species of the Great Lakes Region. Canadian Journal of Forest Research 13:601-608.

Buell, M. F., H. F. Buell, and J. A. Small. 1954. Fire in the history of Mettler's Woods. Bulletin of the Torrey Botanical Club 81:253-255.

Canham, C. D., and O. L. Loucks. 1984. Catastrophic windthrow in the presettlement forests of Wisconsin. Ecology 65:803-809.

Cogbill, C. V. 1985. Dynamics of the boreal forests of the Laurentian Highlands, Canada. Canadian Journal of Forest Research 15:252-261.

Connell, J. H., and M. D. Lowman. 1989. Low diversity tropical rain forests: some possible mechanisms for their existence. American Naturalist 134:88-119.

Connell, J. H., J. G. Tracy, and L. J. Webb. 1984. Compensatory recruitment, growth, and mortality as factors maintaining rain forest tree diversity. Ecological Monographs 54:141-164.

Court, A. 1974. The climate of the conterminous United States. Pages 193-266 in R. A. Bryson and K. F. Hare, editors. Climates of North America. Elsevier, New York, New York, USA.

Curtis, J. T. 1959. The vegetation of Wisconsin. University of Wisconsin Press, Madison, Wisconsin, USA.

Davis, G., and A. Hart. 1961. Effect of seedbed preparation on natural reproduction of spruce and hemlock under dense shade. U.S. Department of Agriculture Forest Service, Northeast Forest Experiment Station Paper 160.

Davis, M. B. 1987. Invasions of forest communities during the Holocene: beech and hemlock in the Great Lakes Region. Pages 373-393 in A. J. Gray, M. J. Crawley, and P. J. Edwards, editors. Colonization, succession and stability. Blackwell Scientific, Oxford, England.

Davis, M. B., K. D. Woods, S. L. Webb, and R. P. Futyma. 1986. Dispersal versus climate: expansion of Fagus and Tsuga into the Upper Great Lakes. Vegetatio 67:93-103.

Dawes, D. S., and N. C. Maravolo. 1973. Isolation and characterization of a possible allelopathic factor supporting the dominant role of Hieracium aurantiacum in the brakengrasslands of northern Wisconsin. Transactions of the Wisconsin Academy of Sciences, Arts, and Letters 61:235-251.

Eyre, F. H., and W. M. Zillgitt. 1953. Partial cuttings in northern hardwoods of the Lake States. U.S. Department of Agriculture Technical Bulletin 1076. 
Forcier, L. K. 1975. Reproductive strategies and co-occurrence of climax tree species. Science 189:808-810.

Foster, D. R. 1988a. Disturbance history, community organization and vegetation dynamics of the old-growth Pisgah Forest, south-western New Hampshire, USA. Journal of Ecology 76:105-134.

- $1988 b$. Species and stand response to catastrophic wind in central New England, USA. Journal of Ecology 76 135-151.

Fowells, H. A. 1965. Silvics of the forest trees of the United States. U.S. Department of Agriculture, Forest Service, Agriculture Handbook Number 271.

Fox, J. F. 1977. Alternation and coexistence of tree species. American Naturalist 111:69-89.

Frelich, L. E. 1986. Natural disturbance frequencies in the hemlock-hardwood forests of the Upper Great Lakes Region. Dissertation. University of Wisconsin-Madison, Madison, Wisconsin, USA.

Frelich, L. E., and C. G. Lorimer. 1985. Current and predicted long-term effects of deer browsing in hemlock forests in Michigan, USA. Biological Conservation 34:99-120.

Frelich, L. E., and C. G. Lorimer. 1991. Natural disturbance regimes in hemlock-hardwood forest of the Upper Great Lakes Region. Ecological Monographs 61:145-164.

Goder, H. A. 1955. A phytosociological study of Tsuga canadensis near the termination of its range in Wisconsin. Dissertation. University of Wisconsin-Madison, Madison, Wisconsin, USA.

Graham, S. A. 1941. The question of hemlock establishment. Journal of Forestry 39:567-569.

Hart, T. B., J. A. Hart, and P. G. Murphy. 1989. Monodominant and species-rich forests of the humid tropics: causes for their co-occurrence. American Naturalist 133 613-633.

Heinselman, M. L. 1973. Fire in the virgin forests of the Boundary Waters Canoe Area, Minnesota. Quaternary Research 3:329-382.

Hemstrom, M. A., and J. F. Franklin. 1982. Fire and other disturbances of the forests in Mount Rainier National Park. Quaternary Research 18:32-51.

Henry, J. D., and J. M. A. Swan. 1974. Reconstructing forest history from live and dead plant material - an approach to the study of forest succession in southwest New Hampshire. Ecology 55:772-783.

Hibbs, D. E. 1982. White pine in the transition hardwood forest. Canadian Journal of Botany 60:2046-2053.

Horn, H. S. 1971. The adaptive geometry of trees. Monographs in Population Biology 3.

Hough, A. L., and R. D. Forbes. 1943. The ecology and silvics of forests in the high plateaus of Pennsylvania. Ecological Monographs 13:300-320.

Hubbell, S. P., and R. B. Foster. 1986. Biology, chance, and history and the structure of tropical rain forest tree communities. Pages 314-329 in J. Diamond and T. J. Case, editors. Community ecology. Harper \& Row, New York, New York, USA.

Jordan, J. K. 1973. A soil resource inventory of the Sylvania Recreation Area. U.S. Department of Agriculture, Forest Service, Ottawa National Forest, Watersmeet, Michigan, USA.

Leebens-Mack, J. H. 1989. Spatial patterns in seed rain density and seedling recruitment of northern mixed hardwood species in Sylvania Wilderness Area, Michigan. Thesis. University of Minnesota, Minneapolis, Minnesota, USA.

Levy, G. F. 1970. The phytosociology of northern Wisconsin upland openings. American Midland Naturalist 83:213237.

Lorimer, C. G. 1983a. Eighty-year development of northern red oak after partial cutting in a mixed-species Wisconsin forest. Forest Science 29:371-383.

- $1983 b$. Tests of age-independent competition in- dices for individual trees in natural hardwood stands. Forest Ecology and Management 6:343-360.

Lorimer, C. G., and L. E. Frelich. 1989. A methodology for estimating canopy disturbance frequency and intensity in dense temperate forests. Canadian Journal of Forest Research 19:651-663.

Milfred, C. J., G. W. Olson, and F. D. Hole. 1967. Soil resources and forest ecology of Menominee County, Wisconsin. University of Wisconsin Geological and Natural History Survey, Soil Series Number 60, Bulletin 85 .

Mladenoff, D. J. 1987. Dynamics of nitrogen mineralization and nitrification in hemlock and hardwood treefall gaps. Ecology 68:1171-1180.

NOAA. 1980a. Climatological data national summary 1980. National Oceanic and Atmospheric Administration, Environmental Data Service, National Climatic Center, Asheville, North Carolina, USA.

- 1980b. Climatological data annual summary - Wisconsin. National Oceanic and Atmospheric Administration, Environmental Data Service, National Climatic Center, Asheville, North Carolina, USA.

Oliver, C. D., and E. P. Stephens. 1977. Reconstruction of a mixed-species forest in central New England. Ecology 58: 562-572.

Paine, R. T., and S. A. Levin. 1981. Intertidal landscapes: disturbance and the dynamics of pattern. Ecological Monographs 55:145-178.

Pastor, J., J. D. Aber, C. A. McClaugherty, and J. M. Melillo. 1982. Soils and vegetation of Blackhawk Island, Wisconsin. American Midland Naturalist 108:266-277.

Pastor, J., J. D. Aber, C. A. McClaugherty, and J. M. Melillo. 1984. Aboveground production and $\mathrm{N}$ and $\mathrm{P}$ cycling along a nitrogen mineralization gradient on Blackhawk Island, Wisconsin. Ecology 65:256-268.

Pastor, J., and M. Broshardt. 1990. The spatial pattern of a northern conifer-hardwood landscape. Landscape Ecology 4:55-68.

Peacock, B. 1986. Sylvania. Park Press, Waite Park, Minnesota, USA.

Peet, R. K., and O. L. Loucks. 1977. A gradient analysis of southern Wisconsin forests. Ecology 58:485-499.

Phillips, D. W., and J. A. W. McCulloch. 1972. The climate of the Great Lakes Basin. Climatological studies number 20. Environment Canada, Atmospheric Environment Service, Toronto, Ontario, Canada.

Romme, W. H. 1982. Fire and landscape diversity in subalpine forests of Yellowstone National Park. Ecological Monographs 52:199-221.

Runkle, J. R. 1981. Gap regeneration in some old-growth forests of the eastern United States. Ecology 62:1041-1051. - 1982. Patterns of disturbance in some old growth mesic forests of eastern North America. Ecology 63:15331546.

Schlesinger, W. H., J. F. Reynolds, G. L. Cunningham, L. F. Huenneke, W. M. Jarrell, R. A. Virginia, and W. G. Whitford. 1990. Biological feedbacks in global desertification. Science 247:1043-1048.

Soil Survey Staff. 1951. Soil survey manual. U.S. Department of Agriculture Handbook 18.

Sokal, R. R., and N. L. Oden. 1978. Spatial autocorrelation in biology. 1. Methodology. Biological Journal of the Linnaean Society 10:199-228.

Spies, T. A., and B. V. Barnes. 1985. A multifactor ecological classification of the northern hardwood and conifer ecosystems of Sylvania Recreation Area, Upper Peninsula, Michigan. Canadian Journal of Forest Research 15:949960.

Sprugel, D. G. 1976. Dynamic structure of wave-regenerated Abies balsamea forest in the northeastern United States. Journal of Ecology 64:889-912.

Thompson, J. N. 1985. Within-patch dynamics of life his- 
tories, populations, and interactions: selection over time in small spaces. Pages 253-265 in S. T. A. Pickett and P. S. White, editors. The ecology of natural disturbance and patch dynamics. Academic Press, Orlando, Florida, USA.

Waggoner, P. E., and G. R. Stephens. 1970. Transition probabilities for a forest. Nature 225:1160-1161.

Wedin, D. A., and D. Tilman. 1990. Species effects on nitrogen cycling: a test with perennial grasses. Oecologia (Berlin) 84:433-441.

Whitney, G. G. 1986. Relation of Michigan's presettlement pine forests to substrate and disturbance history. Ecology 67:1548-1559.
Woods, K. D., and R. H. Whittaker. 1981. Canopy-understory interaction and the internal dynamics of mature hardwood and hemlock-hardwood forests. Pages 305-323 in D. C. West, H. H. Shugart and D. B. Botkin, editors. Forest succession, concepts and application. Springer-Verlag, New York, New York, USA.

Yarie, J. 1981. Forest fire cycles and life tables: a case study from interior Alaska. Canadian Journal of Forest Research 11:554-562. 